\title{
Perbandingan Efek Ranitidin, Dexametason dan Kombinasinya terhadap Kadar Asam Format Darah dan Pelepasan Sitokrom C Retina pada Model Tikus Intoksikasi Metanol Akut
}

\section{Comparison of Ranitidine, Dexamethasone and Their Combination Effect on Blood Formic Acid Level and Retinal Cytochrome C Release of Acute Methanol Intoxication Rat Model}

\author{
Syahira Halisa, Seskoati Prayitnaningsih \\ Laboratorium IImu Kesehatan Mata Rumah Sakit Umum Dr. Saiful Anwar Malang
}

\begin{abstract}
ABSTRAK
Keracunan metanol dapat menyebabkan toksisitas visual. Asam format merupakan metabolit yang bertanggung jawab terhadap terjadinya asidosis metabolik dan toksisitas visual yang menyebabkan kerusakan mitokondria dengan petanda penting pelepasan sitokrom C. Penelitian ini dilakukan untuk mengetahui pengaruh ranitidin dan perbedaannya dengan dexametason serta kombinasinya terhadap kadar asam format darah dan pelepasan sitokrom $\mathrm{C}$ retina tikus coba yang diinduksi metanol akut melalui penelitian eksperimental dengan desain post only with control. Hewan coba tikus Stratus Novergicus strain Wistar dibagi dalam lima kelompok dengan 7 kali pengulangan yaitu kontrol negatif dan positif, dan tiga kelompok perlakuan dengan pemberian ranitidin, dexametason dan kombinasinya secara intraperitoneal. Dilakukan pengukuran kadar asam format dengan metode kolorimetrik pada sampel serum darah dan pelepasan sitokrom C, analisa data menggunakan One Way ANOVA dengan post hoc test. Hasil menunjukkan rerata kadar asam lebih tinggi format pada tikus dengan intoksikasi methanol $(10.441,8 \mathrm{ng} / \mathrm{mL})$ dibandingkan pada kondisi normal $(3.612,6 \mathrm{ng} / \mathrm{mL})$. Pemberian ranitidin menghasilkan kadar asam format yang paling rendah $(2.341,6 \mathrm{ng} / \mathrm{mL})$ dibandingkan pemberian dexametason $(5.919,2 \mathrm{ng} / \mathrm{mL})$ atau kombinasi keduanya $(2.913,2 \mathrm{ng} / \mathrm{mL})$. Pemberian ranitidin memberikan penurunan pelepasan sitokrom C yang paling tinggi $(1.202,058)$ dibandingkan pemberian dexametason $(2.542,796)$ maupun kombinasi keduanya $(1.670,230)$. Dapat disimpulkan Ranitidin memberikan penurunan asam format darah dan pelepasan sitokrom $C$ retina yang paling signifikan bila dibandingkan dengan kelompok pemberian dexametason dan kombinasi ranitidin dexametason pada intoksikasi metanol.
\end{abstract}

Kata Kunci: Asam format, keracunan, metanol, ranitidin, retina, sitokrom C

\begin{abstract}
Methanol intoxication can cause visual toxicity,. Formic acid is a metabolite responsible in metabolic acidosis leading to mitochondrial damage reflected in $C$ sitokrom release. This study is aimed to identify the effect of ranitidine, dexamethasone and their combination on blood formic acid level and retinal cytochrome c release of rats as acute methanol intoxication model. An experimental study was performed using post only with control group design. There were three treatment groups i.e. ranitidine, dexamethasone and their combinations with two control groups i.e. normal untreated rats as negative control and untreated methanol intoxicated rats as positive control. Seven replications were applied on each group. Objects were intoxicated with oral delivery of methanol and received intraperitoneal delivery of ranitidine, dexamethasone and both at the designated dosage and time. Afterward, the blood formic acid level and cytochrome $c$ release were observed. Formic acid level of control and treated groups were quantified by colorimetric method using blood serum samples. Data were analyzed by one-way ANOVA with post hoc test to identify the specific differences. The result demonstrated that the average of blood formic acid levels on methanol intoxicated rats, as positive control, (10441.8 ng/mL) were much higher than that on normal untreated rats, as negative control, (3612.6 ng/mL). Ranitidine therapy show highest decrease on the average of blood formic acid level into $2341.6 \mathrm{ng} / \mathrm{mL} \mathrm{compared} \mathrm{to}$ dexamethasone therapy $(5919.2 \mathrm{ng} / \mathrm{mL})$ or even the combination therapy $(2913.2 \mathrm{ng} / \mathrm{mL})$. Moreover, investigation on retinal cytochrome c release revealed a significant difference between the average value of positive and negative control groups which were 18278.28 and 1680.74, respectively. Ranitidine therapy delivered the highest reduction value of retinal cytochrom c release (1202.06) compared to dexamethasone (2542.80) or the combination of both therapy (1670.23). It can be concluded that ranitidine worked through decreasing blood formic acid level and retinal cytochrome $c$ value and has highest effect, followed by combination and dexamethasone in methanol intoxication.
\end{abstract}

Keywords: Cytochrome C, formic acid, methanol, ranitidine, retinal, toxication

Jurnal Kedokteran Brawijaya, Vol. 26, No. 3 Februari 2011; Korespondensi: Syahira Halisa. Laboratorium IImu Kesehatan Mata Rumah Sakit Dr. Saiful Anwar Malang, Jl. Jaksa Agung suprapto No.2 Malang Tel. (0341) 366242 Email: halisa_s@yahoo.com 


\section{PENDAHULUAN}

Keracunan metanol dapat menyebabkan depresi susunan saraf pusat secara transien diikuti dengan periode laten simtomatik selama 12 sampai 24 jam. Proses intoksikasi selanjutnya terjadi format asidemia, asidosis metabolik yang tidak terkompensasi, toksisitas visual, koma, dan kematian pada beberapa kasus $(1,2)$.

Asam format merupakan metabolit yang bertanggung jawab terhadap terjadinya asidosis metabolik dan toksisitas visual. Proses-proses ini menyebabkan kerusakan mitokondria. Petanda penting terjadinya kerusakan mitokondria adalah pelepasan sitokrom C (2). Sitokrom C merupakan protein yang secara fisiologis terletak di dalam mitokondria dan merupakan salah satu kompleks enzim yang membantu proses transport elektron pada proses pembentukan adenosin tri phosphat. Jika terjadi kerusakan, maka mitokondria akan melepaskan sitokrom C yang menginduksi apoptosis melalui jalur intrinsik.

Penanganan keracunan metanol adalah pemberian antidotum (fomepizole atau etanol), pemberian asam folat, koreksi asidosis, dan hemodialisa untuk meningkatkan eliminasi metanol. Steroid oral dan intravena juga diberikan sebagai terapi dan mampu memperbaiki tajam penglihatan secara signifikan $(3,4)$.

Luasnya efek samping kortikosteroid mendorong kajian terapi alternatif, diantaranya ranitidin. Penelitian yang dilakukan oleh El-Bakary dkk menemukan bahwa ranitidin dapat mengoreksi asidosis metabolik dan menurunkan kadar asam format darah karena keracunan akut metanol. Ranitidin merupakan inhibitor enzim gastrik alkohol dehidrogenase dan hepatik aldehid dehidrogenase sehingga dapat digunakan sebagai antidotum terapeutik pada keracunan metanol $(4,5)$.

Saat ini penanganan toksik optik neuropati karena keracunan metanol di RSSA adalah kortikosteroid intravena dan kortikosteroid oral. Ranitidin diberikan sebagai obat untuk mengatasi efek samping kortikosteroid terhadap mukosa lambung dan bukan sebagai antidotum. Penelitian ini dilakukan untuk membandingkan efek antara ranitidin dan kombinasi ranitidin dan deksametason terhadap kadar asam format darah dan pelepasan sitokrom $\mathrm{C}$ retina tikus coba yang diinduksi metanol.

\section{METODE}

Penelitian in merupakan penelitian eksperimental dengan desain posttest only with control. Perlakuan dalam penelitian ini sebagai variabel bebas adalah pemberian ranitidin dengan dosis $3 \mathrm{~g} / \mathrm{kgBB}$, dexametason dengan dosis $1 \mathrm{~g}$ dalam 500 cc NS sebanyak 16,5 cc dalam 2 jam dan ranitidin dengan dexametason dengan dosis seperti disebutkan sebelumnya. Variabel tergantung atau keluaran yang diukur adalah kadar asam format yang diukur dengan kolorimetrik dengan satuan $\mathrm{ng} / \mathrm{mL}$, dan kadar pelepasan sitokrom $\mathrm{C}$ yang diukur dengan pemeriksaan imunohistokimia dengan satuan jumlah dalam prosentase.

Tikus coba dibagi ke dalam lima kelompok, dengan masing-masing kelompok terdiri dari 5 tikus: dua kelompok kontrol dan tiga kelompok perlakuan. Pada kelompok kontrol negatif, tikus digunakan sebagai referensi nilai normal dan hanya dipapar terhadap $\mathrm{N}_{2} \mathrm{O}: \mathrm{O}_{2}$ (1:1, flow rate $2 \mathrm{~L} / \mathrm{min})$ sepanjang penelitian (16 jam) dengan tujuan untuk menurunkan jumlah asam folat tikus mendekati jumlah asam folat pada manusia, hingga mencapai respon organisme yang paling mendekati dengan respon intoksikasi metanol pada manusia. Pada kelompok kontrol positif, tikus dipapar terhadap $\mathrm{N}_{2} \mathrm{O}: \mathrm{O}_{2}$ (1:1, flow rate $2 \mathrm{~L} / \mathrm{min}$ ) sepanjang penelitian (16 jam), kemudian 4 jam setelah pemberian $\mathrm{N}_{2} \mathrm{O}: \mathrm{O}_{2}$, dimulai tikus di kelompok kontrol positif. Seluruh kelompok perlakuan diberikan metanol secara oral dengan konsentrasi $3 \mathrm{~g} / \mathrm{kgBB}$, dengan menggunakan jarum pungsi lumbal yang telah ditumpulkan, dan kemudian dimatikan setelah 12 jam berikutnya dengan cara dislokasi tulang belakang. Perlakuan pemberian metanol dimulai setelah pemaparan dengan $\mathrm{N}_{2} \mathrm{O}: \mathrm{O}_{2}$ selama 4 jam. Penelitian oleh El- Bakary et al menyebutkan bahwa dengan pemaparan $\mathrm{N}_{2} \mathrm{O}: \mathrm{O}_{2}$ selama 4 jam jumlah asam folat tikus sudah menyerupai pada manusia (5). Metanol yang digunakan adalah metanol 99,9\% diencerkan dalam aquabides dan diberikan sebagai larutan $20 \% \mathrm{w} / \mathrm{v}$.

Ketiga kelompok perlakuan dipapar $\mathrm{N}_{2} \mathrm{O}: \mathrm{O}_{2}(1: 1$, flow rate $2 \mathrm{~L} / \mathrm{min}$ ) sepanjang penelitian (16 jam) dan diberi metanol selama empat jam kemudian diberikan ranitidin secara intraperitoneal $30 \mathrm{mg} / \mathrm{kgBB}$ pada perlakuan 1. Kelompok perlakuan 2 diberikan 1 gram dexametason yang dilarutkan dalam 500 cc NS selama 2 jam. Kelompok perlakuan ketiga diberikan ranitidin $30 \mathrm{mg} / \mathrm{kgBB}$ dan dexametason 1 gram dalam 500 cc NS sebanyak 16,5 cc intraperitoneal dalam 2 jam (5).

Dilakukan pengambilan sampel darah dari jantung untuk dilakukan pengukuran kadar asam format dengan metode kolorimetrik, setelah tikus dimatikan dengan cara dislokasi tulang belakang. Dilakukan pengambilan retina mata tikus untuk melakukan pemeriksaan kadar pelepasan sitokrom Cdengan imunohistokimia.

Sampel darah jantung yang diambil, dibiarkan membeku, serum dipisahkan dan digunakan untuk menilai metabolit metanol (asam format) dengan menggunakan kit Formic Acid Assay dari Megazyme (6). Sebelum sampel berupa serum darah dianalisis dengan kit Formic Acid Assay, perlu dilakukan pemisahan protein untuk penjernihan sampel.

Untuk pengambilan retina dilakukan pemisahan jaringan retina dari sklera secara manual dan steril, dengan menggunakan pinset anatomis. Retina diletakkan dalam buffer mitokondria yang mengandung $20 \mathrm{mM}$ HEPES-KOH ( $\mathrm{pH} 7,5), 10 \mathrm{mM} \mathrm{KCl}, 1,5 \mathrm{mM} \mathrm{MgCl} 2,0,5 \mathrm{mM}$ EDTA, 0,5 mM EGTA, $1 \mathrm{mM}$ phenylmethylsulfonylfluoride, $10 \mu \mathrm{g} / \mathrm{mL}$ leupeptin, $10 \mathrm{\mu g} / \mathrm{mL}$ aprotinin, and $250 \mathrm{mM}$ sukrosa. Setiap langkah dalam prosedur kerja ini dilakukan dengan menggunakan mikroskop operasi (TopCon dengan pembesaran 25 kali).

Uji statistik yang digunakan adalah one way ANOVA untuk menguji model secara keseluruhan dengan post hoc test untuk mengidentifikasi letak perbedaan antar perlakuan.

\section{HASIL}

Perbandingan Efek Ranitidin, Dexametason dan Kombinasinya terhadap Kadar Asam Format Darah pada Tikus Coba Intoksikasi Akut.

Hasil menunjukkan rerata kadar asam format dengan intoksikasi jauh lebih tinggi $(10.441,8 \mathrm{ng} / \mathrm{mL})$ secara 
signifikan dibandingkan kondisi normal $(3.612,6 \mathrm{ng} / \mathrm{mL})$. Pemberian ranitidin menghasilkan kadar asam format yang paling rendah secara signifikan $(2.341,6 \mathrm{ng} / \mathrm{mL})$ dibandingkan pemberian dexametason $(5.919,2 \mathrm{ng} / \mathrm{mL})$ atau kombinasi keduanya $(2.913,2 \mathrm{ng} / \mathrm{mL})$. Meskipun tidak ada perbedaan signifikan kadar asam format pada kelompok perlakuan dengan pemberian ranitidin dan kombinasi ranitidin dexametason, kadar asam format pada pemberian ranitidin mempunyai nilai variasi yang kecil dibandingkan kelompok kombinasi.

Temuan ini membuktikan bahwa pemberian ranitidin, dapat menurunkan kadar asam format pada intoksikasi metanol hingga mendekati nilai asam format pada kondisi normal (kontrol negatif). Pemberian dexametason, dapat menurunkan kadar asam format tetapi belum mencapai kadar asam format normal yang ditunjukkan pada kelompok kontrol negatif. Kombinasi kedua obat tersebut, ranitidin dan dexametason, juga menunjukkan kadar asam format yang lebih rendah dari kondisi intoksinasi hingga mendekati nilai normal.

Tabel 1. Perbedaan rerata kadar asam format darah antar kelompok kontrol dan perlakuan

\begin{tabular}{llcl}
\hline Kelompok & Mean $(\mathrm{N}=5)$ & Standar deviasi & $*$ \\
\hline Kontrol positif & 10.4418 & 1.63219 & $\mathrm{a}$ \\
Kontrol negatif & 3.6126 & 1.90888 & $\mathrm{~b}$ \\
Ranitidin & 2.3416 & .93346 & $\mathrm{~b}$ \\
Dexametason & 5.9192 & 2.07367 & $\mathrm{C}$ \\
Kombinasi & 2.9132 & 1.76222 & $\mathrm{~b}$ \\
\hline
\end{tabular}

*notasi yang berbeda menunjukkan perbedaan yang signifikan

Perbandingan Efek Ranitidin, Dexametason dan Kombinasi terhadap Pelesan Sitokrom C pada Retina Mata Tikus dengan Intoksikasi Metanol Akut

Secara kuantitatif (Tabel 2) pemeriksaan pelepasan sitokrom C pada kelompok kontrol positif didapatkan rerata 18.278,28 dan kelompok kontrol negatif sebanyak $1.680,74$. Didapatkan perbedaan yang besar pada ekspresi sitokrom C antara kondisi intoksikasi (kontrol positif) dan kondisi normal (kontrol negatif). Pemberian ranitidin memberikan kadar pelepasan sitokrom $C$ yang paling rendah $(1.202,058)$ dibandingkan pemberian dexametason $(2.542,796)$ maupun kombinasi keduanya $(1.670,230)$.

Tabel 2. Tabel gambaran pelepasan sitokrom C pada kelompok perlakuan dan kelompok kontrol

\begin{tabular}{lll}
\hline Kelompok & Mean $(\mathrm{N}=5)$ & Standar deviasi \\
\hline Kontrol positif & 18.278 .29 & $2182.51194(\mathrm{a})$ \\
Kontrol negatif & 1.680 .75 & $190.68589(\mathrm{~b})$ \\
Ranitidin & 1.207 .06 & $121.99020(\mathrm{~b})$ \\
Dexametason & 2.542 .79 & $119.83832(\mathrm{c})$ \\
Kombinasi & 1.670 .23 & $97.03711(\mathrm{~b})$ \\
\hline
\end{tabular}

Pada ketiga kelompok perlakukan, didapatkan penurunan pelepasan sitokrom $\mathrm{C}$ dengan hasil yang signifikan. Apabila dibandingkan antara perlakuan pemberian ranitidin dan kombinasi ranitidin dan dexametason, meskipun pelepasan sitokrom C lebih banyak pada kelompok perlakuan kombinasi namun perbedaan tersebut tidak signifikan. Apabila dibandingkan antara kelompok perlakuan dengan ranitidin dan dexametason, pelepasan sitokrom $\mathrm{C}$ secara signifikan lebih banyak pada kelompok perlakuan dengan dexametason. Kelompok perlakuan dengan pemberian dexametason bila dibandingkan dengan perlakuan pemberian kombinasi ranitidin dan dexametason memberikan hasil tidak berbeda secara statistik dengan jumlah pelepasan sitokrom C lebih banyak pada kelompok perlakuan dengan dexametason.

Hasil pemeriksaan pelepasan sitokrom C dengan menggunakan mikroskop confocal yang diamati secara kualitatif dapat dilihat pada Gambar 1. Pelepasan sitokrom $\mathrm{C}$ ditunjukkan dengan gambaran hijau yang berpendar. Secara kualitatif pada kondisi intoksikasi menunjukkan gambaran pelepasan sitokrom $\mathrm{C}$ yang paling banyak dibandingkan semua kelompok lain. Gambaran pelepasan sitokrom $C$ pada pemberian ranitidin dan kombinansi dengan dexametason memberikan gambaran yang hampir sama dengan kontrol negatif.

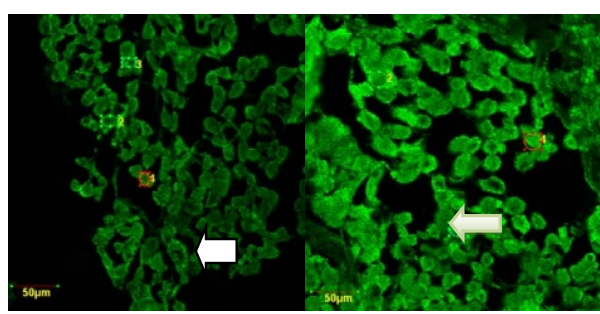

A

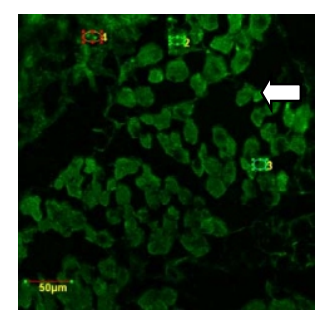

C

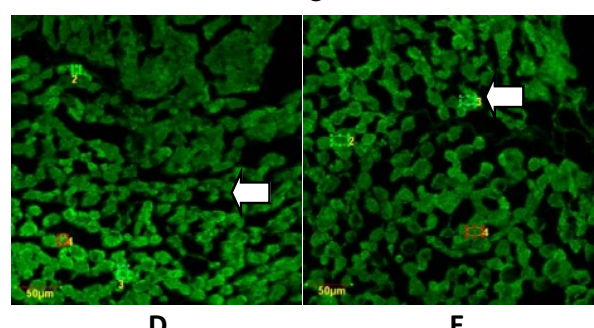

Gambar 1. Hasil pemeriksaan pelepasan sitokrom C dengan menggunakan mikroskop confocal

Keterangan:

A. Gambaran retina mata tikus retina normal (tanpa intoksikasi) pada kelompok kontrol negatif

B. Gambaran pelepasan sitokrom $\mathrm{C}$ pada retina mata tikus intoksikasi metanol akut pada kelompok kontrol positif. Pelepasan sitokrom C tampak dari gambaran yang berpendar warna hijau terang

C. Gambaran pelepasan sitokrom C retina mata tikus intoksikasi metanol akut, dengan pemberian ranitidin. Didapatkan pelepasan sitokrom Cyang berkurang

D. Gambaran retina mata tikus intoksikasi metanol akut pada kelompok perlakuan pemberian dexametason. Didapatkan jumlah sitokrom C yang berkurang

E. Gambaran retina mata tikus intoksikasi metanol akut pada kelompok perlakuan pemberian kombinasi ranitidin dan dexametason. Didapatkan pelepasan sitokrom Cyang menurun 
Perbandingan Efek Ranitidin, Dexamethasone dan Kombinasinya pada Kondisi Intoksikasi Metanol

Hasil penelitian menunjukkan rata-rata nilai kadar asam format dalam darah tampak pada kelompok kontrol positif (intoksikasi metanol akut) menghasilkan asam format dalam jumlah yang terbanyak. Pada kondisi intoksikasi, metanol akan diubah menjadi formaldehid di lambung dengan bantuan alcohol dehydrogenase, selanjutnya dengan segera formaldehid diubah menjadi asam format dengan bantuan aldehid dehydrogenase (7).

Pada kelompok perlakuan dengan pemberian ranitidin, didapatkan nilai asam format yang lebih rendah. Menurut El Bakary et al, ranitidin dapat digunakan sebagai antidotum pada intoksikasi metanol akut, karena fungsinya sebagai alcohol dehydrogenase inhibitor dan aldehid dehydrogenase inhibitor (6).

Pada kelompok perlakuan dexametason, didapatkan kadar asam format yang menurun dibandingkan dengan keadaan intoksikasi dan mendekati normal. Akan tetapi kadarnya masih lebih tinggi bila dibandingkan dengan kelompok perlakuan dengan pemberian ranitidin saja dan kombinasi ranitidin dan dexametason. Data ini mendukung hasil dari penelitian Gulgun $\mathrm{T}$ et al, yang menyebutkan bahwa pada pemberian terapi intoksikasi metanol akut dengan steroid, didapatkan penurunan kadar asam format dengan mekanisme kerja yang belum diketahui (5).

Pada kelompok perlakuan pemberian kombinasi dexametason dan ranitidin didapatkan kadar asam format lebih rendah dari kondisi intoksikasi mendekati kondisi normal, akan tetapi masih sedikit lebih tinggi dibandingkan dengan kelompok perlakuan pemberian ranitidin saja. Belum diketahui apakah kedua obat tersebut memiliki titik tangkap yang sama dalam menurunkan kadar asam format darah dalam keadan intoksikasi metanol akut, karena sampai saat ini belum diketahui mekanisme kerja dexametson dalam menurunkan kadar asam format darah.

Ranitidin terikat pada sitokrom P450, sehingga menurunkan aktivitas enzim mikrosom hati dan mengakibatkan akumulasi obat yang diberikan bersamaan dengan ranitidin. Ranitidin juga menghambat absorpsi dexametason dan mengurangi kadarnya dalam plasma sebanyak $25 \%$ (8). Belum ada literatur maupun penelitian terdahulu yang menyebutkan hubungan antara kerja obat ranitidin, antagonis reseptor $\mathrm{H} 2$ dengan steroid. Maka dari itu, pada pemberian klinisnya perlu dipertimbangkan juga efek samping yang diakibatkan oleh penggunaan dexametason jangka waktu lama, dan biaya yang dikeluarkan dengan penggunaan kedua kombinasi tersebut, mengingat tidak didapatkan efek saling menguatkan dari kedua obat tersebut.

Perbandingan Efek Ranitidin, Deksametason dan Kombinasinya terhadap Pelepasan Sitokrom Retina Mata Tikus Intoksikasi Metanol Akut

Kadar asam format yang tinggi mengakibatkan banyak Fe pada jalur sitokrom oksidasi pada proses fosforilasi oksidasi yang diikat oleh asam format. Kondisi tersebut menyebabkan banyak elektron-elektron bebas disitoplasma sel yang bersifat sebagai radikal bebas sehingga menimbulkan kerusakan pada struktur membran luar mitokondria $(9,10)$. Disamping itu juga terjadi pelepasan sitokrom $\mathrm{C}$ yang merupakan protein yang melekat pada membran dalam mitokondria sebagai stimulasi terjadinya apoptosis melalui jalur intrinsik. Semakin banyak kadar asam format, akan semakin banyak juga sitokrom C yang dilepaskan. Pada kelompok perlakuan dengan pemberian ranitidin, didapatkan pelepasan sitokrom $\mathrm{C}$ lebih rendah bila dibandingkan keadaan intoksikasi yang tergambar pada kontrol positif. Pemberian ranitidin menurunkan kadar asam format lebih rendah dibandingkan kondisi normal, yaitu pada kelompok kontrol negatif. Hal tersebut disebabkan karena perubahan formaldehid menjadi asam format dihambat oleh ranitidin yang merupakan alkohol dan aldehid dehydrogenase inhibitor. Hambatan perubahan metanol menjadi asam format, mengakibatkan penurunan pelepasan sitokrom C yang disebabkan berikatannya asam format dengan $\mathrm{Fe}$, yang mengakibatkan dilepaskannya sitokrom $\mathrm{C}$ dan mengaktifkan jalur intrinsik dari apoptosis (11). Pada perlakuan dengan pemberian dexametason didapatkan pelepasan sitokrom $\mathrm{C}$ yang lebih rendah dari kondisi intoksikasi akut namun masih lebih tinggi bila dibandingkan kondisi normal. Penurunan pelepasan sitokrom C pada kelompok ini disebabkan karena mekanisme kerja dari steroid adalah menghambat ikatan dari TNF $\alpha$ dengan Fas Ligand, sehingga tidak terjadi pengaktifan caspase 8 dan merupakan inisiator protein jalur ekstrinsik dari apoptosis $(5,12)$. Pelepasan sitokrom C pada kelompok kombinasi sedikit lebih rendah dibandingkan dengan kontrol negative. Tidak didapatkan efek sinergis dari kedua obat ini karena titik tangkap yang berbeda dalam menurunkan jumlah pelepasan sitokrom C. Diperlukan penelitian lebih lanjut untuk mengetahui apakah didapatkan efek melemahkan dosis dari pemberian kedua obat tersebut secara bersamaan.

Pemberian dexametason, juga memberikan penurunan yang signifikan pelepasan sitokrom $\mathrm{C}$ dari mitokondria, meskipun penurunan tersebut lebih kecil dibandingkan pemberian ranitidin. Dexametason menghambat pada jalur ekstrinsik apoptosis, yaitu hambatan ikatan TNF $\alpha$ dengan Fas ligand pada dinding luar mitokondria (5). Secara statistik perbedaan antara kelompok ranitidin dan kombinasi tidak berbeda secara signifikan. Disarankan untuk terapi intoksikasi metanol akut dengan pemberian ranitidin saja dan bukan kombinasi dengan dexametason. Hal tersebut dipilih karena mengingat efek samping dari dexameson itu sendiri pada penggunaan jangka panjang, biaya yang dikeluarkan penderita menjadi lebih banyak dan tidak didapatkan efek sinergis dengan penggunaan kedua obat yang sama-sama menurunkan kadar asam format dan pelepasan sitokrom C tersebut. Apabila dibandingkan pelepasan sitokrom $\mathrm{C}$ pada kelompok pemberian dexametason lebih tinggi secara signifikan dibandingkan pemberian ranitidin saja.

Secara keseluruhan hasil penelitian menunjukkan bahwa ranitidin mempunyai efek antidotum terhadap intoksikasi metanol bila diukur berdasarkan kadar asam format dan pelepasan sitokrom C. Efek antidotum tersebut lebih baik dibandingkan pemberian dexametason saja atau kombinasi keduanya. Pemberian dexametason juga ditemukan memberikan efek perdarahan lambung pada dua hewan coba. Perlu penelitian lanjut dengan uji klinis pada manusia untuk mengetahui implikasi hasil penelitian ini pada manusia serta dosis efektif ranitidin. Meskipun tidak lebih baik dibandingkan ranitidin, dexametason juga ditemukan mampu memperbaiki kadar asam format. Mekanisme jalur pengaruh ini masih belum diketahui 
secara jelas sehingga perlu kajian lebih lanjut.

Akurasi penelitian ini sangat dipengaruhi akurasi pengukuran kedua parameter yaitu kadar asam format darah dan pelepasan sitokrom C retina. Pembuatan sediaan menjadi satu faktor yang mempengaruhi hasil pengukuran. Pada salah satu preparat pada kelompok kontrol positif didapatkan hasil false positif. Didapatkan penghitungan ekspresi pelepasan sitokrom $C$ yang sangat tinggi, yaitu $143.640,7$. Hal tersebut disebabkan karena pembuatan sediaan yang tidak sempurna, sehingga pada saat dilakukan pengecatan terdapat pooling pada satu bagian yang memberikan gambaran pendaran pada pemeriksaan dengan mikroskop confocal. Diperlukan pembuatan sediaaan dan pengecatan dengan kehatihatian yang tinggi dan dilakukan oleh operator yang berpengalaman untuk memberikan hasil yang memuaskan.

Fakta kondisi hewan coba dan akurasi pengukuran juga perlu dipertimbangkan pada penelitian berikutnya untuk

\section{DAFTAR PUSTAKA}

1. Jacobsen D, Sebastian CS, Baron SK, Carriere EW, and McMartin KE. Effect of 4-Methylpirazole, Methanol/Ethylen Glycol Antidote, in Health Human. The Journal of Emergency Medicine. 1990; 8(4): 455461.

2. Lieber CS. Alcohol: Its Metabolism and Interaction with Nutrients. Annual Review of Nutrition. 2000; 20: 395-430.

3. Yasmine dan Prayitnaningsih S. The Visual Outcome of Toxic Optic Neuropathy Caused by Alcohol Intoxication Treated with Megadose Intravenous Steroid. Indonesian Ophthalmology Association Annual Meeting. Makasar, 2009.

4. Barceloux D, Bond GR, Krenzelok EP, et al. American Academy of Clinical Toxicology Practice Guidelines on the Treatment of Methanol Poisoning. Journal of Toxicology-Clinical Toxicology. 2002; 40(4): 415-446.

5. Tezel G and Yang X. Caspase Independent Component of Retina Ganglion Cell Death, In Vitro. Investigative Opthalmology \& Visual Science. 2004; 45(11): 40494059.

6. El-Bakary AA, El-Dakrory SA, Attalla SM, Hasanein NA, and Malek HA. Ranitidin as an Alcohol Dehydrogenase Inhibitor in Acute Metanol Toxicity in Rats. Human \& Experimental Toxicology. 2010; 29(2): 93-101.

7. Zrenner E and Hart W. Drug Induced and Toxic menetapkan minimal jumlah pengulangan dalam satu kelompok perlakuan. Penelitian ini mencatat setidak 1-2 pengurangan hewan coba yang disebabkan karena kematian hewan coba atau akurasi pemeriksaan dan pengukuran. Disarankan pada penelitian untuk mempertimbangkan faktor drop out $20-30 \%$ sehingga didapatkan jumlah pengulangan yang tepat.

Hal yang menarik pada studi ini adalah pada kelompok kombinasi didapatkan hasil yang lebih baik dari dexametason, akan tetapi kurang dibandingkan dengan pemberian ranitidin saja. Dibutuhkan penelitian lebih lanjut mengenai mekanisme kerja dexametason dalam menurunkan kadar asam format darah, sehingga dapat diketahui efek dexametason pada pemberian kombinasi dengan ranitidin, apakah saling menguatkan, tidak berpengaruh atau saling melemahkan. Studi ini menunjukkan adanya potensi ranitidin sebagai antidotum intoksikasi metanol, akan tetapi dibutuhkan penelitian lebih lanjut pada manusia.

Disorder in Neuro Ophthalmology. In: Schielfer U (Ed). Clinical Neuro-Ophthalmology. New York: Springer Berlin Heidelberg; 2007; p. 223-232.

8. Hovda KE and Jacobsen D. Fomepizole May Ameliorate the Need of Hemodialysis in Metanol Poisioning. Human \& Experimental Toxicology. 2008; 27(7): 539-546

9. Garcia-Ruiz G, Collel A, Morales A, Kaplowitz N, and Fernandez-Checa JC. Role of Oxidative Stress Generated from the Mitochondrial Electron Transport Chain and Mitochondrial Glutathione Status in Loss of Mitochondrial Function and Activation of Transcriptional Factor Nf-\{Kappa\} B: Studies with Isolated Mitochondria and Rat Hepatocytes. Molecular Pharmacology. 1995; 48(5): 825-834.

10. Seme MT, Summerfelt $P$, Neitz J, Eells JT, and Henry MM. Differential Recovery of Retinal Function After Mitochondrial Inhibition by Methanol Intoxication. Investigative Ophthalmology \& Visual Science. 2001; 42(3): 834-841.

11. Seme MT, Summerfelt P, Henry MM, Neitz J, and Eells JT. Formate Induced Inhibition of Photoreceptor Function in Methanol Intoxication. Journal of Pharmacology and Experimental Therapeutics. 1999; 289(1): 361-370.

12. Bang JS, Yang HS, Rho SS, and Chang YH. A Case of Toxic Amblyopia Caused by Methanol Intoxication. Journal of the Korean Ophthalmological Society. 2007; 48(12): $1731-1738$ 